\title{
Chemical composition, antioxidant activity and bioaccessibility studies in phenolic extracts of two Hericium wild edible species
}

Sandrina A. Heleno ${ }^{\mathrm{a}, \mathrm{b}}$, Lillian Barros ${ }^{\mathrm{a}}$, Anabela Martinss ${ }^{\mathrm{a}}$, Maria João R.P. Queiroz ${ }^{\mathrm{b}}$, Patricia Morales $^{\mathrm{c}}$, Virginia Fernández-Ruiz ${ }^{\mathrm{c}}$, Isabel C.F.R. Ferreira, ${ }^{\mathrm{a},}$

${ }^{a}$ Centro de Investigação de Montanha (CIMO), ESA, Instituto Politécnico de Bragança, Campus de Santa Apolónia, apartado 1172, 5301-854 Bragança, Portugal.

${ }^{b}$ Centro de Química, Universidade do Minho, Campus de Gualtar 4710-057 Braga, Portugal.

${ }^{c}$ Departamento de Nutrición y Bromatología II. Bromatología. Facultad de Farmacia, Universidad Complutense de Madrid (UCM), Plaza Ramón y Cajal s/n, E- 28040 Madrid, Spain.

* Author to whom correspondence should be addressed (Isabel C.F.R. Ferreira; e-mail: iferreira@ipb.pt; telephone +351-273-303219; fax +351-273-325405).

Running Title: Bioaccessibility studies in phenolic extracts of Hericium species 


\begin{abstract}
Mushrooms are rich sources of bioactive compounds such as phenolic acids. When ingested, these molecules have to be released from the matrix to be transformed/absorbed by the organism, so that they can exert their bioactivity. Several in vitro methodologies have been developed in order to evaluate the bioavailability of bioactive compounds. Herein, two Hericium species were analyzed for their chemical composition and antioxidant activity. Furthermore, an in vitro digestion of the mushrooms and mushroom phenolic extracts was performed, and the digested samples were also submitted to antioxidant activity evaluation in order to evaluate the bioaccessibility of the phenolic acids identified in the samples. Hericium species showed similar chemical profiles (except for tocopherols), varying only in the concentration of the compounds. The phenolic extracts revealed higher antioxidant activity than the in vitro digested samples, meaning that this process decrease the antioxidant properties of the extract/mushroom. Nevertheless, phenolic acids were found in the digested samples, meaning that those molecules are bioaccessible.
\end{abstract}

Keywords: Wild mushrooms; chemical composition; antioxidant activity and bioaccessibility; phenolic extracts 


\section{Introduction}

Wild mushrooms have been extensively consumed since the primords of human civilization, due to their unique and delicate flavor, being rich sources of minerals and having high amounts of water, protein, fiber, and carbohydrates. Lipids are present in low values, which make them excellent to be included in low-caloric diets (Heleno, Barros, Sousa, Martins \& Ferreira, 2009; Kalac, 2009; Kalac, 2012).

Beyond the nutritional characteristics, mushrooms have been also extensively studied for their medicinal properties, mainly due to their richness in bioactive compounds that presented antioxidant, anticancer and antimicrobial properties, among other bioactivities (Ferreira, Barros \& Abreu, 2009; Ferreira, Vaz, Vasconcelos \& Martins, 2010; Alves, Ferreira, Dias, Teixeira, Martins \& Pintado, 2012).

Phenolic acids are the major low molecular weight bioactive components usually found in mushroom species, responsible for their antioxidant properties (Ferreira et al., 2009). Once ingested, these bioactive compounds have to be released from the matrix and modified in the gastrointestinal tract so that they become accessible to be absorbed in the intestine (Bouayed, Hoffmann \& Bohn, 2011; Rodríguez-Roque, Rojas-Graü, ElezMartínez \& Martín-Belloso, 2013; Carbonell-Capella, Buniowska, Barba, Esteve \& Frígola, 2014).

Bioaccessibility is usually evaluated by in vitro digestion procedures, generally simulating gastric and small intestinal digestion; sometimes followed by Caco-2 cells uptake to evaluate the bioavailability (Courraud, Berger, Cristol \& Avallone, 2013). With the aim of evaluating if the compounds are bioaccessible, in vitro methodologies have been developed as an attempt to mimic the in vivo conditions. Those assays are described as being easy, cheap and reproducible, being possible to evaluate the digestive stability of the food constituents (Failla \& Chitchumroonchokchai, 2005; Rodríguez- 
Roque et al., 2013). Furthermore, in some cases, the use of in vitro models to study the bioaccessibility of food constituents have proven to be well correlated with results from human studies and animal models (Biehler \& Bohn, 2010; Bouayed et al., 2011).

Our daily diet could be enriched with food rich in antioxidant such as fruits, vegetables and mushrooms in order to help the organism in the combat against oxidative stress, taking advantage of the additive and synergistic effects of all the antioxidant compounds present. Public health authorities consider prevention with nutraceuticals/functional foods as a powerful instrument in maintaining and promoting health, longevity and life quality (Ferreira et al., 2009). Nevertheless, it is important to guarantee the bioaccessibility and bioavailability of the ingested compounds.

Therefore, in the present work, two wild edible mushroom species originated from our region (Northeast Portugal) (Hericium erinaceus (Bull.) Persoon and Hericium coralloides (Scop.) Pers., were analyzed for their nutritional value, detailed chemical composition and antioxidant properties. Furthermore, in order to evaluate the bioaccessibility of the compounds responsible for the mushrooms antioxidant properties, a digestion of the dry powder and extracts enriched in phenolic acids was performed under in vitro conditions.

\section{Materials and methods}

\subsection{Samples and samples preparation}

Specimens of Hericium erinaceus (Bull.) Persoon and Hericium coralloides (Scop.) Pers., two edible mushrooms belonging to the Hericiaceae family, were collected in Bragança (Northeast Portugal) during November of 2013. These species are saprobic and can also be parasitic, typically fruiting from fallen hardwoods branches and stumps; they are widely distributed and common. After authentication, voucher specimens were 
deposited at herbarium of School of Agriculture of Polytechnic Institute of Bragança, Portugal. The specimens were immediately lyophilised (FreeZone 4.5, Labconco, Kansas, USA), reduced to a fine dried powder (20 mesh), mixed to obtain an homogenate sample and kept at $-20^{\circ} \mathrm{C}$ until further analysis.

For phenolic extracts preparation, $1.5 \mathrm{~g}$ of each dry mushroom powder was twice extracted with a mixture of methanol $(800 \mathrm{~mL} / \mathrm{L})$ and water $(200 \mathrm{~mL} / \mathrm{L})$ at $-20{ }^{\circ} \mathrm{C}$ for $1.5 \mathrm{~h}$; after a sonication step for $15 \mathrm{~min}$, the extract was filtered through Whatman No. 4 paper (Barros et al., 2009). The combined extracts were evaporated under reduced pressure at $30^{\circ} \mathrm{C}$ to remove methanol.

\subsection{Standards and Reagents}

Acetonitrile 99.9\%, n-hexane 95\% and ethyl acetate 99.8\% were of HPLC grade from Fisher Scientific (Lisbon, Portugal). The fatty acids methyl ester (FAME) reference standard mixture 37 (standard 47885-U) was purchased from Sigma (St. Louis, MO, USA), as well as other individual fatty acid isomers and standards of sugars (L-(+)arabinose, D-(+)-mannitol, D-(+)-trehalose), tocopherols ( $\alpha-, \beta-, \delta$ - and $\gamma$-isoforms), organic acids (malic, oxalic and fumaric acids), phenolic compounds (gallic, $p$ hydroxybenzoic, and p-coumaric acids), Trolox (6-hydroxy-2,5,7,8tetramethylchroman-2-carboxylic acid), dietary fiber enzyme kit (TDF-100A Kit), pepsin (P-7000), pancreatin (P-1750) and porcine bile (B-8631). Racemic tocol, 50 $\mathrm{mg} / \mathrm{mL}$, was purchased from Matreya (PA, USA). 2,2-Diphenyl-1-picrylhydrazyl (DPPH) was obtained from Alfa Aesar (Ward Hill, MA, USA). Micro (Fe, $\mathrm{Cu}, \mathrm{Mn}$ and $\mathrm{Zn})$ and macroelements $\left(\mathrm{Ca}, \mathrm{Mg}, \mathrm{Na}\right.$ and $\mathrm{K}$ ) standards (>99\% purity), as well $\mathrm{LaCl}_{2}$ and $\mathrm{CsCl}$ (>99\% purity) were purchased from Merck (Darmstadt, Germany). Anthrone 
was obtained from Panreac (Barcelona, Spain). Water was treated in a Milli-Q water purification system (TGI Pure Water Systems, Greenville, SC, USA).

\subsection{Chemical composition}

2.3.1. Proximate composition. The samples were analysed for moisture, proteins, fat, carbohydrates and ash, using the AOAC procedures (AOAC, 1995). The crude protein content $(\mathrm{N} \times 4.38)$ of the samples was estimated by the macro-Kjeldahl method; the crude fat was determined by extracting a known weight of powdered sample with petroleum ether, using a Soxhlet apparatus; the ash content was determined by incineration at $600 \pm 15^{\circ} \mathrm{C}$.

Total available carbohydrate (TAC) assay was carried out by the anthrone method as described by Osborne \& Voogt (1986) using $0.25 \mathrm{~g}$ of sample. The samples were pretreated with $13 \mathrm{~mL}$ of $52 \mathrm{~mL} / 100 \mathrm{~mL} \mathrm{HClO}_{4}$ and kept for $18 \mathrm{~h}$ in the dark. After this period, distilled water was added, the sample was filtered and the volume of the filtrate was adjusted to $100 \mathrm{~mL}$. Finally, the solution was further diluted to $10 \mathrm{~mL} / 100 \mathrm{~mL}$, and $5 \mathrm{~mL}$ of $0.1 \mathrm{~mL} / 100 \mathrm{~mL}$ anthrone solution in $73 \mathrm{~mL} / 100 \mathrm{~mL} \mathrm{H}_{2} \mathrm{SO}_{4}$ was added. Samples were kept in a boiling water bath for 12 min where the anthrone reaction with sugars yielded a green colour, and absorbance was measured at $630 \mathrm{~nm}$ on a UV/Vis Spectrometer EZ210 (Perkin Elmer, Waltham, MA, USA) equipped with Lambda software PESSW ver. 1.2. The absorbance of the sample solution was compared to a 10$100 \mu \mathrm{g} / \mathrm{mL}$ concentration range standard glucose calibration curve. TAC values were expressed as $\mathrm{g} / 100 \mathrm{~g}$ of dry weight.

AOAC enzymatic-gravimetric methods (993.19 and 991.42) were used for soluble dietary fiber (SDF) and insoluble dietary fiber (IDF) analysis (Latimer, 2012). In brief, freeze-dried samples were treated with $0.1 \mathrm{~mL}$ of heat-stable $\alpha$-amylase in $50 \mathrm{~mL}$ 
phosphate buffer ( $\mathrm{pH} \mathrm{6)}$ and incubated in a water bath at $100^{\circ} \mathrm{C}$, during $15 \mathrm{~min}$, after cooling the $\mathrm{pH}$ was adjusted to 7.5 with $\mathrm{NaOH}(0.275 \mathrm{~N}) 5 \mathrm{mg}$ of protease was added and incubated at $60^{\circ} \mathrm{C}$ during $30 \mathrm{~min}$. Finally, $0.3 \mathrm{~mL}$ of amyloglucosidase was added after the $\mathrm{pH}$ was adjusted to 4.5 with $\mathrm{HCl}(0.325 \mathrm{~N})$, and incubated at $60^{\circ} \mathrm{C}$ during 30 min; all the incubations was performed under continuous agitation. The soluble and insoluble fractions were separated by vacuum filtration. Waste from the digests was dried at $100{ }^{\circ} \mathrm{C}$. Total fiber was calculated as the sum of soluble and insoluble fiber, both were expressed as $\mathrm{g} / 100 \mathrm{~g}$ of dry weight.

Energy content was calculated according to the following equation according to Regulation $(\mathrm{EC})$ No. 1169/ 2011: Energy $(\mathrm{kcal})=4 \times(\mathrm{g}$ protein $+\mathrm{g}$ total available carbohydrate $)+2 \times(\mathrm{g}$ fiber $)+9 \times(\mathrm{g}$ fat $)$

2.3.2. Macro and microelements. Total mineral content (ashes) and mineral elements analysis were performed on dried samples. AOAC method No. 930.05 was used; 500 $\mathrm{mg}$ of each sample was subject to dry-ash mineralization at $450^{\circ} \mathrm{C}$. The incineration residue was extracted with $\mathrm{HCl} 0.5 \mathrm{~mL} / \mathrm{mL}$ and $\mathrm{HNO}_{3} 0.5 \mathrm{~mL} / \mathrm{mL}$ and made up to a suitable volume of distilled water to which were directly weighed $\mathrm{Fe}, \mathrm{Cu}, \mathrm{Mn}$ and $\mathrm{Zn}$. The other elements were determined after dilutions (Fernández-Ruiz et al., 2004; RuizRodríguez et al., 2011). All measurements were performed in atomic absorption spectroscopy (AAS) with air/acetylene flame in Analyst 200 Perkin Elmer equipment (Perkin Elmer, Waltham, MA, USA), comparing absorbance responses with $>99.9 \%$ purity analytical standard solutions for AAS made with $\mathrm{Fe}\left(\mathrm{NO}_{3}\right)_{3}, \mathrm{Cu}\left(\mathrm{NO}_{3}\right)_{2}, \mathrm{Mn}$ $\left(\mathrm{NO}_{3}\right)_{2}, \mathrm{Zn}\left(\mathrm{NO}_{3}\right)_{2}, \mathrm{NaCl}, \mathrm{KCl}, \mathrm{CaCO}_{3}$ and $\mathrm{Mg}$ band, supplied by Merck (Darmstadt, Germany) and Panreac Química (Barcelona, Spain). 
2.3.3. Free sugars. Free sugars were determined by a High Performance Liquid Chromatography (HPLC) system consisted of an integrated system with a pump (Knauer, Smartline system 1000, Berlin, Germany), degasser system (Smartline manager 5000) and auto-sampler (AS-2057 Jasco, Easton, MD, USA), coupled to a refraction index detector (RI detector Knauer Smartline 2300) as previously described by the authors (Heleno et al., 2009). Sugars were identified by comparing the relative retention times of sample peaks with standards. Data were analyzed using Clarity 2.4 Software (DataApex, Prague, Czech Republic). Quantification was based on the RI signal response of each standard, using the internal standard (IS, raffinose) method and by using calibration curves obtained from commercial standards of each compound. The results were expressed in g per $100 \mathrm{~g}$ of dry weight.

2.3.4. Fatty acids. Fatty acids were determined after a transesterification procedure as described previously by the authors (Heleno et al., 2009), using a gas chromatographer (DANI 1000, Contone, Switzerland) equipped with a split/splitless injector and a flame ionization detector (GC-FID). Fatty acid identification was made by comparing the relative retention times of FAME peaks from samples with standards. The results were recorded and processed using CSW 1.7 software (DataApex 1.7, Prague, Czech Republic). The results were expressed in relative percentage of each fatty acid.

2.3.5. Tocopherols. Tocopherols were determined by following a previously described procedure (Heleno, Barros, Sousa, Martins \& Ferreira, 2010). Analysis was performed by HPLC (equipment described above), and with fluorescence detector (excitation 290 $\mathrm{nm}$, emission $330 \mathrm{~nm}$ ). The compounds were identified by chromatographic comparisons with authentic standards. Quantification was based on the fluorescence 
signal response of each standard, using the IS (tocol) method and by using calibration curves obtained from commercial standards of each compound. The results were expressed in $\mu \mathrm{g}$ per $100 \mathrm{~g}$ of dry weight.

2.3.6. Organic acids. Organic acids were determined by following previously described procedure (Reis et al., 2013). Analysis was performed by ultra-fast liquid chromatograph (UFLC) coupled to photodiode array detector (PDA), using a Shimadzu 20A series UFLC (Shimadzu Corporation, Kyoto, Japan). Detection was carried out in a PDA, using $215 \mathrm{~nm}$ and 245 as preferred wavelengths. The organic acids were quantified by comparison of the area of their peaks recorded at $215 \mathrm{~nm}$ with calibration curves obtained from commercial standards of each compound. The results were expressed in g per $100 \mathrm{~g}$ of dry weight.

\subsection{In vitro gastrointestinal model (dialysis) for bioaccessibility studies}

Bioaccessibility was determined using $25 \mathrm{~mL}$ of aqueous solutions prepared from dry mushroom powder $(20 \mathrm{mg} / \mathrm{mL})$ or lyophilized phenolic extract $(50 \mathrm{mg} / \mathrm{mL})$ as decribed by (Ramírez-Moreno, Marquês, Sánchez-Mata \& Goñi, 2011).

The gastric digestion was simulated, adjusting the $\mathrm{pH}$ of each sample to 2, adding 150 $\mathrm{mL}$ of a pepsin solution ( $40 \mathrm{mg} / \mathrm{mL}$ of $\mathrm{HCl} 0.1 \mathrm{~mol} / \mathrm{L})$, and incubating the mixture in a water bath at $37^{\circ} \mathrm{C}$ for $2 \mathrm{~h}$ with stirring ( $60 \mathrm{osc} / \mathrm{min}$ ). The intestinal digestion was then simulated, adding to the mentioned mixture a pancreatin/bile solution $(5 / 25 \mathrm{mg}$ of pancreatin/bile per $1 \mathrm{~mL}$ of $\mathrm{NaHCO}_{3} 0.1 \mathrm{~mol} / \mathrm{L}$ ) for 3 hours. The mixture was then transferred to dialysis membranes (Medicell 7000/2, width $34 \mathrm{~mm}, 7000 \mathrm{Mw}$ cut off), previously boiled in distilled water for $15 \mathrm{~min}$. The dialysis membranes/mixture was then placed in to a flask containing $250 \mathrm{~mL}$ of $\mathrm{NaHCO}_{3} \mathrm{pH} 7.5$ and incubated in a water 
bath at room temperature for $3 \mathrm{~h}$ with stirring $(60 \mathrm{osc} / \mathrm{min})$. After dialysis, the obtained final solution of $\mathrm{NaHCO}_{3} \mathrm{pH} 7.5$ was frozen and lyophilized for evaluation of antioxidant activity and phenolic compounds analysis.

\subsection{Antioxidant activity}

2.5.1. General. Successive dilutions of the stock solution of the phenolic extract, in vitro digested mushroom powder and in vitro digested phenolic extract, were made and submitted to in vitro assays already described by the authors (Heleno et al., 2009) to evaluate the antioxidant activity of the samples. The sample concentrations providing $50 \%$ of antioxidant activity or 0.5 of absorbance $\left(\mathrm{EC}_{50}\right)$ were calculated from the graphs of antioxidant activity percentages (DPPH, $\beta$-carotene/linoleate and TBARS assays) or absorbance at $690 \mathrm{~nm}$ (reducing power assay) against sample concentrations. In the Folin-Ciocalteu assay, the results were expressed as $\mathrm{mg}$ of gallic acid equivalents (GAE) per g of extract. The commercial standard Trolox was used as positive control.

2.5.2. Reducing power. Two different procedures were used to evaluate the reducing power: A). The first methodology, the ferricyanide Prussian blue assay, was performed following the method first reported by Oyaizu et al., 1986 with some modifications, using a Microplate Reader ELX800 Microplate Reader (Bio-Tek Instruments, Inc., Winooski, VT, USA). The different concentrations of the extracts $(0.5 \mathrm{~mL})$ were mixed with sodium phosphate buffer $(200 \mathrm{mmol} / \mathrm{L}, \mathrm{pH}$ 6.6, $0.5 \mathrm{~mL})$ and potassium ferricyanide $(10 \mathrm{~g} / \mathrm{L}, 0.5 \mathrm{~mL})$. For each concentration, the mixture was incubated at 50 ${ }^{\circ} \mathrm{C}$ for $20 \mathrm{~min}$, and trichloroacetic acid $(100 \mathrm{~g} / \mathrm{L}, 0.5 \mathrm{~mL})$ was added. The mixture $(0.8$ $\mathrm{mL})$ was poured in the 48 -wells, as also deionized water $(0.8 \mathrm{~mL})$ and ferric chloride $(1$ $\mathrm{g} / \mathrm{L}, 0.16 \mathrm{~mL}$ ), and the absorbance was measured at $690 \mathrm{~nm}$. B) The second 
methodology followed the Folin-Ciocalteu assay first described by Wolfe et al., 2003. The extract solution $(1 \mathrm{~mL})$ was mixed with Folin-Ciocalteu reagent $(5 \mathrm{~mL}$, previously diluted ten folds with water) and sodium carbonate $(75 \mathrm{~g} / \mathrm{L}, 4 \mathrm{~mL})$. The tubes were vortex mixed for $15 \mathrm{~s}$ and allowed to stand for $30 \mathrm{~min}$ at $40{ }^{\circ} \mathrm{C}$ for colour development. Absorbance was then measured at $765 \mathrm{~nm}$.

2.5.3. DPPH scavenging activity assay. This methodology was performed following Hatano et al. (1988) first description with some modifications, by using the Microplate Reader mentioned above. The reaction mixture on 96 wells plate consisted of a solution by well of the extract solutions with different concentrations $(30 \mu \mathrm{L})$ and methanolic solution $(270 \mu \mathrm{L})$ containing DPPH radicals $\left(6 \times 10^{-5} \mathrm{~mol} / \mathrm{L}\right)$. The mixture was left to stand for $30 \mathrm{~min}$ in the dark, and the absorption was measured at $515 \mathrm{~nm}$. The radical scavenging activity (RSA) was calculated as a percentage of DPPH discolouration using the equation: $\%$ RSA $=\left[\left(A_{D P P H}-A_{S}\right) / A_{D P P H}\right] \times 100$, where $A_{S}$ is the absorbance of the solution containing the sample, and $\mathrm{A}_{\mathrm{DPPH}}$ is the absorbance of the DPPH solution.

\subsubsection{Lipid peroxidation inhibition. Lipid peroxidation inhibition was assessed by using} two different approaches: The first methodology was $\beta$-carotene/linoleate assay by following the methodology first described by Burda and Oleszek, 2001 with some modifications: A solution of $\beta$-carotene was prepared by dissolving $\beta$-carotene $(2 \mathrm{mg}$ ) in chloroform $(10 \mathrm{~mL})$. Two millilitres of this solution were pipetted into a roundbottom flask. The chloroform was removed at $40^{\circ} \mathrm{C}$ under vacuum and linoleic acid (40 $\mathrm{mg})$, Tween 80 emulsifier (400 $\mathrm{mg})$, and distilled water $(100 \mathrm{~mL})$ were added to the flask with vigorous shaking. Aliquots $(4.8 \mathrm{~mL})$ of this emulsion were transferred into test tubes containing extract solutions with different concentrations $(0.2 \mathrm{~mL})$. The tubes 
were shaken and incubated at $50^{\circ} \mathrm{C}$ in a water bath. As soon as the emulsion was added to each tube, the zero time absorbance was measured at $470 \mathrm{~nm}$. $\beta$-Carotene bleaching inhibition was calculated using the following equation: ( $\beta$-carotene content after $2 \mathrm{~h}$ of assay/initial $\beta$-carotene content $) \times 100$. The second methodology was TBARS (thiobarbituric acid reactive species) assay following Kishida et al. (1993) with some modifications: Porcine (Sus scrofa) brains were obtained from official slaughtering animals, dissected, and homogenized with a Polytron in ice cold Tris-HCl buffer (20 $\mathrm{mmol} / \mathrm{L}, \mathrm{pH} 7.4$ ) to produce a $5 \mathrm{~g} / \mathrm{L}$ brain tissue homogenate which was centrifuged at $3000 \mathrm{~g}$ for $10 \mathrm{~min}$. An aliquot $(100 \mu \mathrm{L})$ of the supernatant was incubated with the different concentrations of the samples solutions $(200 \mu \mathrm{L})$ in the presence of $\mathrm{FeSO}_{4}(10$ $\mathrm{mmol} / \mathrm{L} ; 100 \mu \mathrm{L})$ and ascorbic acid $(0.1 \mathrm{mmol} / \mathrm{L} ; 100 \mu \mathrm{L})$ at $37^{\circ} \mathrm{C}$ for $1 \mathrm{~h}$. The reaction was stopped by the addition of trichloroacetic acid $(280 \mathrm{~g} / \mathrm{L}, 500 \mu \mathrm{L})$, followed by thiobarbituric acid (TBA, $20 \mathrm{~g} / \mathrm{L}, \mathrm{w} / \mathrm{v}, 380 \mu \mathrm{L}$ ), and the mixture was then heated at $80^{\circ} \mathrm{C}$ for $20 \mathrm{~min}$. After centrifugation at $3000 \mathrm{~g}$ for $10 \mathrm{~min}$ to remove the precipitated protein, the colour intensity of the malondialdehyde (MDA)-TBA complex in the supernatant was measured by its absorbance at $532 \mathrm{~nm}$. The inhibition ratio (\%) was calculated using the following formula: Inhibition ratio $(\%)=[(\mathrm{A}-\mathrm{B}) / \mathrm{A}] \times 100 \%$, where A and B were the absorbance of the control and the sample solution, respectively.

\subsection{Analysis of phenolic compounds}

The phenolic extracts previously described in section 2.1 . were submitted to a liquidliquid extraction with diethyl ether $(2 \times 20 \mathrm{~mL})$ and ethyl acetate $(2 \times 20 \mathrm{~mL})$. Anhydrous sodium sulphate was added to the combined organic phases and the extracts were filtrated through Whatman No. 4 paper, evaporated to dryness and re-dissolved in a mixture of methanol $(200 \mathrm{~mL} / \mathrm{L})$ and water $(800 \mathrm{~mL} / \mathrm{L})$ (Barros et al., 2009). The 
extracts $(1 \mathrm{ml})$ were filtered through a $0.22 \mu \mathrm{m}$ nylon disposable LC filter disk. Phenolic acids determination was performed using a Shimadzu 20A series ultra-fast liquid chromatograph (UFLC, Shimadzu, equipment described above) as previously described by Reis et al. (2013). Detection was carried out in a photodiode array detector (PDA), using $280 \mathrm{~nm}$ as the preferred wavelength. The phenolic compounds were quantified by comparison of the area of their peaks recorded at $280 \mathrm{~nm}$ with calibration curves obtained from commercial standards of each compound. The results were expressed in $\mu \mathrm{g}$ per $100 \mathrm{~g}$ of dry phenolic extract or $100 \mathrm{~g}$ of dry mushroom.

\subsection{Statistical analysis}

Three specimens of each mushroom species were used, and all the assays were carried out in triplicate. The results were expressed as mean values and standard deviation (SD), and further analyzed using one-way analysis of variance (ANOVA) followed by Tukey's HSD Test with $\alpha=0.05$. This treatment was carried out using SPSS v. 22.0 program. In the case of proximate composition, free sugars, fatty acids, tocopherols and organic acids a student's $t$-test was used because there were less than three groups. This treatment was carried out using SPSS v. 22.0 program.

\section{Results and Discussion}

\subsection{Chemical composition}

The results of Hericium erinaceus and H. coralloides proximate composition, free sugars and fatty acids contents are shown in Table 1. Carbohydrates, total available carbohydrates (TAC) and fiber fraction, were the most abundant macronutrients, and among them fiber provided a higher contribution than TAC and free sugars. Insoluble dietary fiber (IDF) content was higher than soluble dietary fiber (SDF); this tendency 
and content values are in agreement with the ones reported in literature for mushrooms in general (Kalac, 2012). H. erinaceus presented the double content of proteins (which contribute to a higher energetic value), but contents slightly lower of TAC, fibers and fat than $H$. coralloides.

Arabinose, mannitol and trehalose were found in both samples, but arabinose was the most abundant sugar, followed by mannitol and trehalose (Table 1). H. erinaceus gave the highest amount of total free sugars due to the highest concentration of arabinose and mannitol. In literature, arabinose has been reported as one of the minor sugars present in mushrooms (Kalac, 2012), but for the species studied herein, arabinose was the major sugar. High levels of arabinose seem to be a characteristic of the genus Hericinum (Keong, Rashid, Ing \& Ismail, 2007; Han, Ye \& Wang, 2013). Regarding fatty acids composition of $H$. erinaceus, saturated fatty acids (SFA) predominated over polyunsaturated (PUFA) and monounsaturated (MUFA) fatty acids, due to the high contents of palmitic (C16:0) and stearic (C18:0) acids (Table 1). For H. coralloides the contents of SFA, PUFA and MUFA were similar. Oleic (C18:1n9c) and linoleic (C18:2n6c) acids were also found in higher percentages, mainly in $H$. coralloides.

Mushrooms have been reported in literature as sources of mineral elements (Mattila et al., 2001; Kalac, 2012). In the present study, the macroelements $\mathrm{Ca}, \mathrm{Mg}, \mathrm{Na}$ and $\mathrm{K}$, and the microelements $\mathrm{Fe}, \mathrm{Cu}, \mathrm{Mn}$ and $\mathrm{Zn}$ were identified in the two samples (Table 2). $\mathrm{K}$ was the macroelement present in higher levels, followed by $\mathrm{Na}, \mathrm{Mg}$ and $\mathrm{Ca}$ in both samples; Fe was the microelement detected in higher amounts, followed by $\mathrm{Zn}, \mathrm{Cu}$ and Mn, also, in both samples. Several authors described $\mathrm{K}$ as the major macroelement in mushrooms (Kalac, 2013), which is in agreement with our results. Nevertheless, calcium and sodium have been described in literature as the less abundant ones (Kalac, 2013). H. coralloides showed higher contents of macro and microelements, mostly Fe, 
probably due to the environmental conditions of the mushroom growth that have influence on the concentration of metal absorption by mushrooms (Gençcelep et al., 2009).

Regarding tocopherols, $\alpha$-isoform was found in both species, but in higher amounts in $H$. erinaceus, while $\beta$ - and $\gamma$-isoforms were only identified in $H$. erinaceus, and $\delta$ isoform only in H. coralloides (Table 3). The content in total tocopherols was similar in both species. Despite not having $\beta$ - and $\gamma$-tocopherols in its composition, $H$. coralloides gave a significant content of $\delta$-isoform. Concerning to organic acids, oxalic, malic and fumaric acids were also quantified in both species (Table 3), but malic and fumaric acids were the most abundant ones. H. erinaceus presented the highest total organic acids content, due to the high contribution of malic acid.

\subsection{Bioaccessibility studies and antioxidant potential}

The results of antioxidant activity (reducing power, free radicals scavenging activity and lipid peroxidation inhibition) of the phenolic extracts, in vitro digested fruiting bodies and in vitro digested phenolic extracts are expressed in Table 4.

In the literature it is possible to find some reports on the antioxidant activity of $H$. erinaceus. Mau, Lin \& Song (2002) reported $\mathrm{EC}_{50}$ values of $5.06 \mathrm{mg} / \mathrm{mL}$ and 4.46 $\mathrm{mg} / \mathrm{mL}$ in the DPPH and ferrycianide Prussian blue assays, respectively. Otherwise, Unekwu, Audu, Makun \& Chidi (2014) also studied the antioxidant activity of $H$. erinaceus and reported a weak activity in the mentioned assays. The value described by Mau et al. (2002) in Folin-Ciocalteu assay (12.05 mg GAE/g extract) was similar to the one obtained in the present study. As far as we know, there are no previous reports on the antioxidant activity of $H$. coralloides. 
For almost all the antioxidant activity assays, the phenolic extracts showed the highest potential, presenting the lowest $\mathrm{EC}_{50}$ values and the highest concentration in phenolic acids (Table 4). Nevertheless, in the Ferricyanide/Prussian blue assay, in vitro digested phenolic extracts presented the highest reducing power.

The phenolic extracts revealed the highest antioxidant activity for almost all the assays, followed by the in vitro digested phenolic extracts and the in vitro digested mushrooms. The decrease in the antioxidant activity after gastrointestinal digestion is related with the decrease in the phenolic content present in those samples. During gastrointestinal digestion, phenolic acids may undergo structural modifications caused by drastic $\mathrm{pH}$ variations (mainly alkaline $\mathrm{pH}$ conditions), by the action of the enzymes used in the digestion that can alter the molecules by changing the bioactive groups such as the loss of hydrogens that results in a significant loss of the antioxidant activity, and to the presence of phenolic acids linked to other molecules or to the food matrix that difficults the cross through dialysis membrane (Bermúdez-Soto, Tomás-Barberán \& GarcíaConesa, 2007; Rodríguez-Roque et al., 2013).

Phenolic acids are described as being important compounds that contribute to the antioxidant activity of mushrooms due to the presence of $\mathrm{OH}$ groups in their structures that are known for their ability to scavenge free radicals (Heleno et al., 2012). Thus, a significant loss or change of those $\mathrm{OH}$ groups during the gastrointestinal digestion can result in a decrease in their antioxidant capacity.

In the present study, we can attribute the loss of antioxidant activity to the decrease in phenolic acids (gallic, $p$-hydroxybenzoic and $p$-coumaric acids) concentration observed for in vitro digested phenolic extracts (Figure 1) and, mostly, in mushroom fruiting bodies. 
The results obtained are in agreement with other reports in the same subject; RodríguezRoque et al. (2013) studied the changes in phenolic compounds (isoflavones) and antioxidant activity of soymilk after in vitro gastrointestinal digestion and also verified that gastric digestion significantly influenced the release of bioactive substances from the soymilk matrix. The authors concluded that after in vitro gastrointestinal digestion the concentration of those bioactive molecules was significantly lower than in the nondigested ones, as also described by Bouayed et al. (2011) that studied the presence of phenolics, flavonoids, anthocyanins and the antioxidant activity of apples at different phases of simulated digestion using an extended in vitro model. These authors described that after in vitro digestion the concentration of these compounds was significantly lower as well as the antioxidant activity.

It should be highlighted that after in vitro digestion, the mushrooms kept antioxidant capacity (antioxidant activity and phenolic acids), but in lower levels, being the percentage of dialyzed phenolic acids of $9.65 \%$ and $7.89 \%$ for $H$. erinaceus and $H$. coralloides, respectively. Although being less active after gastrointestinal digestion, the bioactive molecules are still bioaccessible.

\section{Conclusion}

As far as we know, this is the first report on the chemical composition of $H$. erinaceus and $H$. coralloides, studying also their antioxidant properties after in vitro gastrointestinal digestion. The wild samples of $H$. erinaceus and $H$. coralloides are low caloric foods (low fat contents) and rich sources of carbohydrates (namely, fibers and free sugars), proteins, minerals and also bioactive compounds (namely, phenolic compounds and tocopherols). The phenolic extracts presented the highest antioxidant activity that is in agreement with the highest concentration in phenolic acids found in 
those samples before in vitro digestion, meaning that after in vitro gastrointestinal digestion, the bioactive compounds can suffer structural changes (losing the $\mathrm{OH}$ groups responsible for the antioxidant activity) that decreased the antioxidant properties. Nevertheless, they are bioaccessible and can have different bioactivities.

\section{Acknowledgments}

The authors are grateful to Fundação para a Ciência e a Tecnologia (FCT, Portugal) for financial support to CIMO (strategic project PEst-OE/AGR/UI0690/2011), S.A. Heleno grant (BD/70304/2010) and L. Barros contract under "Programa Compromisso com a Ciência-2008”.

\section{References}

Alves, M.J., Ferreira, I.C.F.R., Dias, J., Teixeira, V., Martins, A., \& Pintado, M. (2012). A Review on Antimicrobial Activity of Mushroom (Basidiomycetes) Extracts and Isolated Compounds. Planta Medica, 78, 1707-1718.

AOAC (1995). Official methods of analysis (16th Ed.). Arlington VA, USA: Association of Official Analytical Chemists.

Barros, L., Dueñas, M., Ferreira, I.C.F.R., Baptista, P., \& Santos-Buelga, C. (2009). Phenolic acids determination by HPLC-DAD-ESI/MS in sixteen different Portuguese wild mushrooms species. Food and Chemical Toxicology, 47, 10761079.

Bermúdez-Soto, M. A., Tomás-Barberán, F. A., \& García-Conesa, M. T. (2007). Stability of polyphenols in chokeberry (Aronia melanocarpa) subjected to in vitro gastric and pancreatic digestion. Food Chemistry, 102, 865-874. 
Biehler, E., \& Bohn, T. (2010). Methods for assessing aspects of carotenoid bioavailability. Current Nutrition \& Food Science, 6, 44-69.

Bouayed, J., Hoffmann, L., \& Bohn, T. (2011). Total phenolics, flavonoids, anthocyanins and antioxidant activity following simulated gastro-intestinal digestion and dialysis of apple varieties: Bioaccessibility and potential uptake. Food Chemistry, 128, 14-21.

Burda, S., Oleszek, W. (2001). Antioxidant and antiradical activities of flavonoids. Journal of Agricultural and Food Chemistry, 49, 2774-2779.

Carbonell-Capella, J. M., Buniowska, M., Barba, F. J., Esteve, M. J., \& Frígola, A. (2014). Analytical Methods for Determining Bioavailability and Bioaccessibility of Bioactive Compounds from Fruits and Vegetables: A Review. Comprehensive Reviews in Food Science and Food Safety, 13, 155-171.

Courraud, J., Berger, J., Cristol, J.P., \& Avallone, S. (2013). Stability and bioaccessibility of different forms of carotenoids and vitamin A during in vitro digestion. Food Chemistry, 136, 871-7.

Failla, M.L. \& Chitchumroonchokchai, C. (2005). In vitro models as tools for screening the relative bioavailabilities of provitamin A carotenoids in foods. HarvestPlus Technical Monograph, 3, p.32.

Fernández-Ruiz, V., Galiana, L., Sánchez-Mata, M.C., Chaya, C., Roselló, S., Cámara, M., Torija, M.E., \& Nuez, F. (2004). Internal quality characterization of fresh tomato fruits. HortScience, 39, 339-345.

Ferreira, I.C.F.R., Barros, L., \& Abreu, R.M.V. (2009). Antioxidant in Wild mushrooms. Current Medicinal Chemistry, 16, 1543-1560. 
Ferreira, I.C.F.R., Vaz, J.A., Vasconcelos, M.H., \& Martins, A. (2010). Compounds from Wild Mushrooms with Antitumor Potential. Anti-Cancer Agents in Medicinal Chemistry, 10, 424-436.

Gençcelep, H., Uzun, Y., Tunçtürk, Y., Demirel, K. (2009). Determination of mineral contents of wild-grown edible mushrooms. Food Chemistry, 113, 1033-1036.

Han, Z.-H., Ye, J.-M., \& Wang, G.-F. (2013). Evaluation of in vivo antioxidant activity of Hericium erinaceus polysaccharides. International Journal of Biological Macromolecules, 52, 66-71.

Hatano, T., Kagawa, H., Yasuhara, T., \& Okuda, T. (1988). Two new flavonoids and other constituents in licorice root: their relative astringency and radical scavenging effects. Chemical and Pharmaceutical Bulletin, 36, 2090-2097.

Heleno, S.A., Barros, L., Sousa, M.J., Martins, A., \& Ferreira, I.C.F.R. (2009). Study and characterization of selected nutrients in wild mushrooms from Portugal by gas chromatography and high performance liquid chromatography. Microchemical Journal, 93,195-199.

Heleno, S.A., Barros, L., Sousa, M.J., Martins, A., \& Ferreira, I.C.F.R. (2010). Tocopherols composition of Portuguese wild mushrooms with antioxidant capacity. Food Chemistry, 119, 1443-1450.

Heleno, S. A., Barros, L., Martins, A., Queiroz, M.-J.R. P., Santos-Buelga, C., Ferreira, I.C.F.R. (2012). Phenolic, Polysaccharidic, and Lipidic Fractions of Mushrooms from Northeastern Portugal: Chemical Compounds with Antioxidant Properties. Journal of Agricultural and Food Chemistry, 60, 4634-4640.

Kalac, P. (2009). Chemical composition and nutritional value of European species of wild growing mushrooms: A review. Food Chemistry, 113, 9-16. 
Kalac, P. (2012). Chemical composition and nutritional value of European species of wild growing mushrooms, In Mushrooms: types, properties and nutrition. Editors: S. Andres and N. Baumann. Nova Science Publishers, 130-151.

Kalac, P. (2013). A review of chemical composition and nutritional value of wildgrowing and cultivated mushrooms. Journal of the Science of Food and Agriculture, 93, 209-218.

Keong, C.Y., Rashid, B.A.A., Ing, Y.S., \& Ismail, Z. (2007). Quantification and identification of polysaccharide contents in Hericium erinaceus. Nutrition and Food Science, 37, 260-271.

Kishida E., Tokumaru S., Ishitani Y., Yamamoto M., Oribe M., Iguchi H., Kojo S. (1993). Comparison of the formation of malondialdehyde and thiobarbituric acidreactive substances from autoxidized fatty acids based on oxygen consumption. Journal of Agricultural and Food Chemistry, 41, 1598-1600.

Latimer, G.W. (2012). Official methods of analysis of AOAC international (18th ed.). Gaithersburg: EEUU.

Mattila, P., Konko, K., Eurola, M., Pihlava, J. M., Astola, J., Vahteristo, L., Hietaniemi, V., Kumpulainen, J., Valtonen, M., \& Piironen, V. (2001). Contents of vitamins, mineral elements, and some phenolic compounds in cultivated mushrooms. Journal of Agricultural and Food Chemistry, 49, 2343-2348.

Mau, J.-L., Lin, H.-C., \& Song, S.-F. (2002). Antioxidant properties of several specialty mushrooms. Food Research International, 35, 519-526.

Osborne, D.R., \& Voogt, P. (1986). Análisis de los nutrientes de los alimentos. (pp. 258). Zaragoza: Ed. Acribia. 
Oyaizu, M. (1986). Studies on products of browning reactions: antioxidative activities of products of browning reaction prepared from glucosamine. Japanese Journal of Nutrition, 44, 307-315.

Ramírez-Moreno, E., Marquês, C.D., Sánchez-Mata, M.C., \& Goñi, I. (2011). In vitro calcium bioaccessibility in raw and cooked cladodes of prickly pear cactus (Opuntia ficus-indica L. Miller). LWT - Food Science and Technology, 44, 1611, 1615.

Reis, F.S., Barros, L., Calhelha, R.C., Cirić, A., van Griensven, L.J., Soković, M., \& Ferreira, I.C.F.R. (2013). The methanolic extract of Cordyceps militaris (L.) Link fruiting body shows antioxidant, antibacterial, antifungal and antihuman tumor cell lines properties. Food and Chemical Toxicology, 62, 91-98.

Rodríguez-Roque, M.J., Rojas-Graü, M.A., Elez-Martínez, P., \& Martín-Belloso, O. (2013). Soymilk phenolic compounds, isoflavones and antioxidant activity as affected by in vitro gastrointestinal digestion. Food Chemistry, 136, 206-212.

Ruiz-Rodríguez, B., Morales, P., Fernández-Ruiz, V., Sánchez-Mata, M.C.; Cámara, M., Díez-Marqués, C., Santayana, M.P., Molina, M., \& Tardío, J. (2011). Valorization of wild strawberry tree fruits (Arbutus unedo L.) through nutritional assessment and natural production data. Food Research International, 44, 12441253

The European Parliament and of the Council of 25 October 2011 (22.11.2011). Regulation (EC) No. 1169/2011 of the European Parliament and of the Council of 25 October 2011 on the provision of food information to consumers. Official Journal of the European Union, 304, 18-63 (L 304/18-63). 
Unekwu, H.R., Audu, J.A., Makun, M.H., \& Chidi, E.E. (2014). Phytochemical screening and antioxidant activity of methanolic extract of selected wild edible Nigerian mushrooms. Asian Pacific Journal of Tropical Disease, 4, 153-157.

Wolfe K, Wu X and Liu RH. (2003). Antioxidant activity of apple peels. Journal of Agricultural and Food Chemistry, 51, 609-614. 
Table 1. Proximate composition, free sugars and fatty acids in the two wild edible mushroom fruiting bodies.

\begin{tabular}{llll}
\hline & $\begin{array}{l}\text { Hericium } \\
\text { erinaceus }\end{array}$ & $\begin{array}{l}\text { Hericium } \\
\text { coralloides }\end{array}$ & $\begin{array}{l}\text { Student's } t \text {-test } \\
p \text {-value }\end{array}$ \\
\hline Proximate composition (g/100 g dw) & & & \\
\hline Ash & $3.49 \pm 0.20$ & $9.31 \pm 0.47$ & $<0.001$ \\
Total carbohydrates & $79.36 \pm 0.32$ & $81.06 \pm 0.34$ & 0.003 \\
Total available carbohydrates & $31.29 \pm 0.92$ & $38.04 \pm 0.24$ & 0.001 \\
Total Dietary Fiber & $41.32 \pm 1.46$ & $44.28 \pm 0.94$ & 0.008 \\
$\quad$ Insoluble Dietary Fiber & $38.66 \pm 1.88$ & $40.06 \pm 0.77$ & 0.346 \\
$\quad$ Soluble Dietary Fiber & $2.66 \pm 0.29$ & $4.33 \pm 0.42$ & 0.001 \\
Total Free Sugars (g/100 g dw) & $23.63 \pm 0.94$ & $10.79 \pm 0.51$ & $<0.001$ \\
$\quad$ Arabinose & $17.46 \pm 0.70$ & $6.25 \pm 0.32$ & $<0.001$ \\
$\quad$ Mannitol & $5.63 \pm 0.22$ & $3.86 \pm 0.17$ & $<0.001$ \\
$\quad$ Trehalose & $0.54 \pm 0.07$ & $0.68 \pm 0.03$ & 0.032 \\
Proteins & $15.40 \pm 0.38$ & $7.25 \pm 0.15$ & $<0.001$ \\
Fat & $1.75 \pm 0.27$ & $2.38 \pm 0.14$ & 0.007 \\
Energy (kcal/100 g dw) & $394.79 \pm 0.95$ & $374.67 \pm 1.84$ & $<0.001$ \\
\hline Fatty acids (relative percentage) & & & $<0.001$ \\
\hline C16:0 & $37.57 \pm 2.23$ & $23.34 \pm 0.66$ & $<0.001$ \\
C18:0 & $7.61 \pm 0.72$ & $6.78 \pm 0.48$ & 0.079 \\
C18:1n9c & $26.11 \pm 1.25$ & $33.74 \pm 0.39$ & $<0.001$ \\
C18:2n6c & $25.10 \pm 0.35$ & $30.90 \pm 0.20$ & $<0.001$ \\
SFA & $47.57 \pm 1.47$ & $33.51 \pm 0.13$ & $<0.001$ \\
MUFA & $26.80 \pm 1.19$ & $34.59 \pm 0.39$ & $<0.001$ \\
PUFA & $25.63 \pm 0.28$ & $31.90 \pm 0.22$ & $<0.001$ \\
\hline & & & \\
\hline & & & \\
\hline
\end{tabular}

dw- dry weight; Palmitic acid (C16:0); Stearic acid (C18:0); Oleic acid (C18:1n9c); Linoleic acid (C18:2n6c). SFA- saturated fatty acids; MUFA- monounsaturated fatty acids; PUFA- polyunsaturated fatty acids. The difference to $100 \%$ corresponds to other 20 less abundant fatty acids (data not shown). In each row, different letters mean significant differences between samples $(p<0.05)$. The number of replications was $n=9$. 
Table 2. Macro and microelements in the two wild edible mushroom fruiting bodies.

\begin{tabular}{|c|c|c|c|}
\hline & $\begin{array}{l}\text { Hericium } \\
\text { erinaceum }\end{array}$ & $\begin{array}{l}\text { Hericium } \\
\text { coralloides }\end{array}$ & $\begin{array}{l}\text { Student's } t \text {-test } \\
p \text {-value }\end{array}$ \\
\hline \multicolumn{4}{|c|}{ Macroelements (mg/100 g dw) } \\
\hline $\mathrm{Ca}$ & $44.35 \pm 3.58$ & $83.75 \pm 3.24$ & $<0.001$ \\
\hline $\mathrm{Mg}$ & $85.57 \pm 3.49$ & $134.00 \pm 3.80$ & $<0.001$ \\
\hline $\mathrm{Na}$ & $586.78 \pm 2.20$ & $678.04 \pm 11.32$ & $<0.001$ \\
\hline K & $1188.05 \pm 13.14$ & $1778.47 \pm 139.37$ & $<0.001$ \\
\hline \multicolumn{4}{|c|}{ Microelements (mg/100 g dw) } \\
\hline $\mathrm{Fe}$ & $6.77 \pm 0.06$ & $77.96 \pm 3.64$ & $<0.001$ \\
\hline $\mathrm{Cu}$ & $0.22 \pm 0.02$ & $0.72 \pm 0.07$ & $<0.001$ \\
\hline $\mathrm{Mn}$ & $0.09 \pm 0.01$ & $0.31 \pm 0.03$ & $<0.001$ \\
\hline $\mathrm{Zn}$ & $2.11 \pm 0.12$ & $4.76 \pm 0.48$ & $<0.001$ \\
\hline
\end{tabular}

dw- dry weight. In each row, different letters mean significant differences between samples $(p<0.05)$. The number of replications was $\mathrm{n}=9$. 
Table 4. Bioaccessibility studies and antioxidant potential of phenolic extracts and fruiting bodies of the two wild edible mushrooms.

\begin{tabular}{|c|c|c|c|c|c|c|c|}
\hline & & \multicolumn{3}{|c|}{ Hericium erinaceus } & \multicolumn{3}{|c|}{ Hericium coralloides } \\
\hline & & $\begin{array}{c}\text { Phenolic } \\
\text { extract }\end{array}$ & $\begin{array}{l}\text { In vitro digested } \\
\text { mushroom }\end{array}$ & $\begin{array}{l}\text { In vitro digested } \\
\text { phenolic extract }\end{array}$ & $\begin{array}{c}\text { Phenolic } \\
\text { extract }\end{array}$ & $\begin{array}{l}\text { In vitro digested } \\
\text { mushroom }\end{array}$ & $\begin{array}{l}\text { In vitro digested } \\
\text { phenolic extract }\end{array}$ \\
\hline \multicolumn{8}{|l|}{ Antioxidant activity } \\
\hline \multirow{2}{*}{ Reducing power } & $\begin{array}{l}\text { Folin-ciocalteu } \\
\text { (mg GAE/g extract) }\end{array}$ & $13.41 \pm 0.41^{\mathrm{a}}$ & $2.76 \pm 0.01^{\mathrm{c}}$ & $5.61 \pm 0.03^{b}$ & $16.29 \pm 0.15^{\mathrm{a}}$ & $3.00 \pm 0.04^{\mathrm{c}}$ & $8.41 \pm 0.15^{\mathrm{b}}$ \\
\hline & $\begin{array}{l}\text { Ferricyanide/Prussian blue } \\
\left(\mathrm{EC}_{50} ; \mathrm{mg} / \mathrm{mL}\right)\end{array}$ & $3.47 \pm 0.07^{\mathrm{b}}$ & $9.40 \pm 0.22^{\mathrm{a}}$ & $2.43 \pm 0.03^{c}$ & $1.63 \pm 0.12^{b}$ & $4.10 \pm 0.02^{\mathrm{a}}$ & $1.23 \pm 0.00^{\mathrm{c}}$ \\
\hline Scavenging activity & $\begin{array}{l}\text { DPPH scavenging activity } \\
\left(\mathrm{EC}_{50} ; \mathrm{mg} / \mathrm{mL}\right)\end{array}$ & $24.53 \pm 0.77^{\mathrm{c}}$ & $60.14 \pm 3.78^{a}$ & $43.94 \pm 1.96^{\mathrm{b}}$ & $22.53 \pm 0.49^{c}$ & $64.45 \pm 2.09^{\mathrm{a}}$ & $56.31 \pm 2.37^{b}$ \\
\hline \multirow{2}{*}{$\begin{array}{l}\text { Lipid peroxidation } \\
\text { inhibition }\end{array}$} & $\begin{array}{l}\beta \text {-carotene/linoleate } \\
\left(\mathrm{EC}_{50} ; \mathrm{mg} / \mathrm{mL}\right)\end{array}$ & $0.27 \pm 0.00^{\mathrm{c}}$ & $21.51 \pm 1.83^{\mathrm{a}}$ & $4.42 \pm 0.11^{\mathrm{b}}$ & $0.28 \pm 0.00^{\mathrm{c}}$ & $16.37 \pm 0.45^{\mathrm{a}}$ & $8.73 \pm 0.67^{\mathrm{b}}$ \\
\hline & $\begin{array}{l}\text { TBARS } \\
\left(\mathrm{EC}_{50} ; \mathrm{mg} / \mathrm{mL}\right)\end{array}$ & $1.37 \pm 0.03^{\mathrm{c}}$ & $4.93 \pm 0.40^{b}$ & $7.81 \pm 0.99^{\mathrm{a}}$ & $0.74 \pm 0.09^{\mathrm{c}}$ & $3.70 \pm 0.03^{b}$ & $5.68 \pm 0.19^{\mathrm{a}}$ \\
\hline \multicolumn{8}{|l|}{ Phenolic compounds } \\
\hline Gallic acid & $(\mu \mathrm{g} / 100 \mathrm{~g} \mathrm{dw})$ & $76.25 \pm 0.04^{\mathrm{a}}$ & $8.01 \pm 0.40^{\mathrm{c}}$ & $15.63 \pm 0.38^{\mathrm{b}}$ & $133.16 \pm 0.75^{\mathrm{a}}$ & $9.92 \pm 0.12^{\mathrm{c}}$ & $22.03 \pm 0.20^{\mathrm{b}}$ \\
\hline$p$-Hydroxybenzoic acid & $(\mu \mathrm{g} / 100 \mathrm{~g} \mathrm{dw})$ & $73.99 \pm 2.43^{\mathrm{a}}$ & $\operatorname{tr}$ & $1.10 \pm 0.14^{\mathrm{b}}$ & $94.59 \pm 1.40^{\mathrm{a}}$ & $\operatorname{tr}$ & $2.10 \pm 0.03^{b}$ \\
\hline$p$-Coumaric acid & $(\mu \mathrm{g} / 100 \mathrm{~g} \mathrm{dw})$ & $138.02 \pm 0.08^{\mathrm{a}}$ & $19.81 \pm 0.03^{\mathrm{c}}$ & $39.74 \pm 0.16^{\mathrm{b}}$ & $146.96 \pm 1.77^{\mathrm{a}}$ & $19.64 \pm 0.01^{\mathrm{c}}$ & $39.36 \pm 0.05^{\mathrm{b}}$ \\
\hline Total phenolic acids & $(\mu \mathrm{g} / 100 \mathrm{~g} \mathrm{dw})$ & $288.25 \pm 2.48^{\mathrm{a}}$ & $27.82 \pm 0.37^{\mathrm{c}}$ & $55.37 \pm 0.54^{\mathrm{b}}$ & $374.70 \pm 1.12^{\mathrm{a}}$ & $29.55 \pm 0.13^{\mathrm{c}}$ & $61.39 \pm 0.25^{\mathrm{b}}$ \\
\hline
\end{tabular}

tr- Traces; Concerning the Folin-Ciocalteu assay, higher values mean higher reducing power; for the other assays, the results are presented in $\mathrm{EC}_{50}$ values, what means that higher values correspond to lower reducing power or antioxidant potential. $\mathrm{EC}_{50^{-}} \mathrm{Extract}_{\mathrm{s}}$ concentration corresponding to $50 \%$ of antioxidant activity or 0.5 of absorbance for the Ferricyanide/Prussian blue assay. DPPH- 2,2-diphenyl-1-picrylhydrazyl radical; GAE- Gallic acid equivalents; TBARS- Thiobarbituric acid reactive substances. Trolox (commercial standard) was used as positive control $\left(\mathrm{EC}_{50} \leq 0.04 \mathrm{mg} / \mathrm{mL}\right)$. In each row, and for each mushroom species, different letters imply significant differences $(p<0.05)$. The number of replications was $\mathrm{n}=9$. 


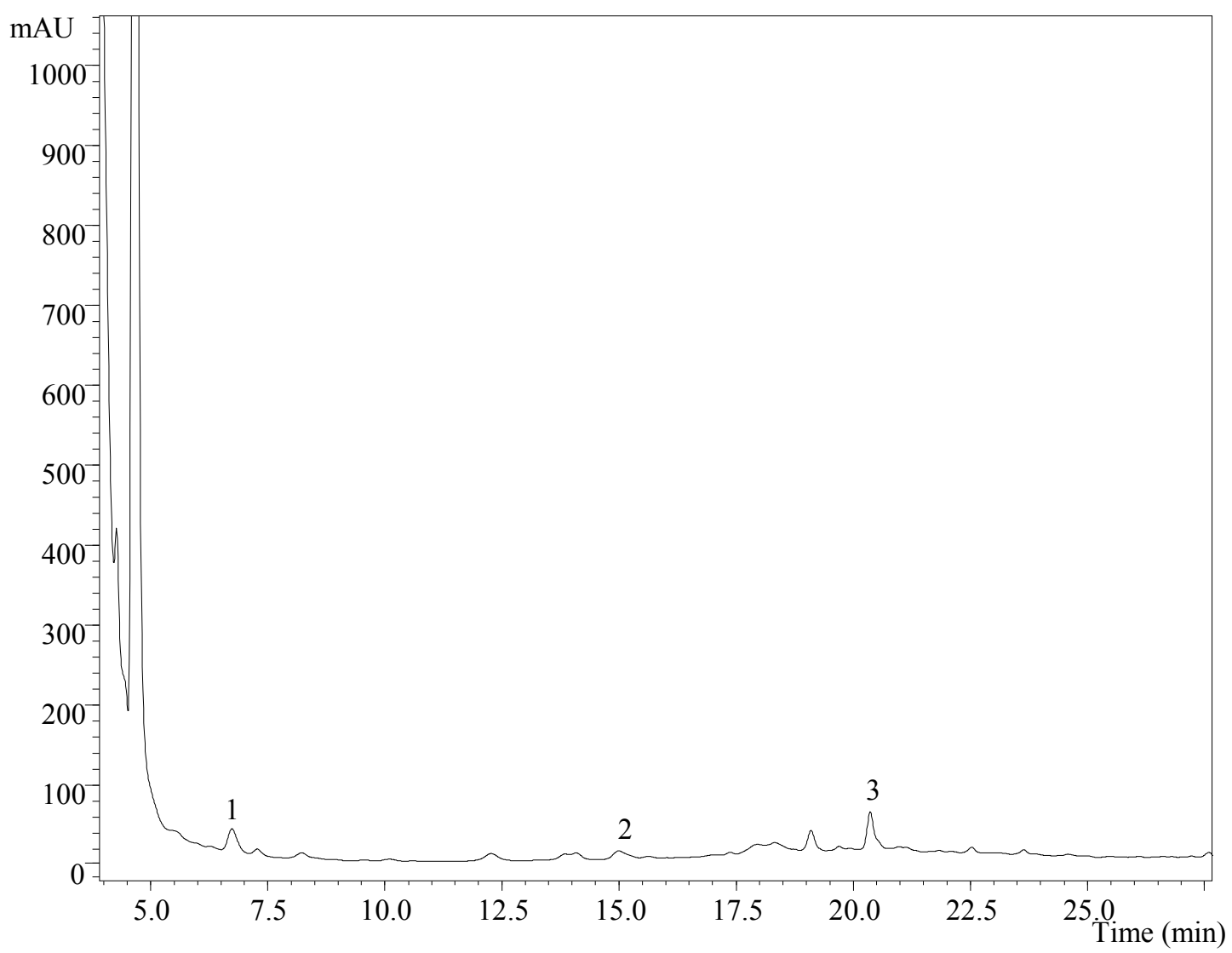

Figure 1. Chromatographic profile of Hericium erinaceus in vitro digested phenolic extract recorded at $280 \mathrm{~nm}$. 1-Gallic acid; 2- $p$-Hydroxybenzoic acid; 3- $p$-Coumaric acid. 
Table 3. Tocopherols and organic acids in the two wild edible mushroom fruiting bodies.

\begin{tabular}{llll}
\hline & $\begin{array}{l}\text { Hericium } \\
\text { erinaceus }\end{array}$ & $\begin{array}{l}\text { Hericium } \\
\text { Coralloides }\end{array}$ & $\begin{array}{l}\text { Student's } t \text {-test } \\
p \text {-value }\end{array}$ \\
\hline Tocopherols $(\mu \mathrm{g} / 100 \mathrm{~g} \mathrm{dw})$ & & & \\
\hline$\alpha$-tocopherol & $46.10 \pm 1.30$ & $30.10 \pm 0.76$ & $<0.001$ \\
$\beta$-tocopherol & $54.90 \pm 1.82$ & $\mathrm{nd}$ & - \\
$\gamma$-tocopherol & $11.28 \pm 1.52$ & $\mathrm{nd}$ & - \\
$\delta$-tocopherol & $\mathrm{nd}$ & $80.87 \pm 7.42$ & - \\
Total tocopherols & $112.28 \pm 1.00$ & $110.97 \pm 6.65$ & 0.658 \\
\hline Organic acids $(\mathrm{g} / 100 \mathrm{~g} \mathrm{dw})$ & & & \\
\hline Oxalic acid & $0.06 \pm 0.00$ & $0.09 \pm 0.00$ & $<0.001$ \\
Malic acid & $3.09 \pm 0.04$ & $0.47 \pm 0.05$ & $<0.001$ \\
Fumaric acid & $0.60 \pm 0.01$ & $0.37 \pm 0.00$ & $<0.001$ \\
Total organic acids & $3.75 \pm 0.03$ & $0.93 \pm 0.05$ & $<0.001$ \\
\hline
\end{tabular}

dw- dry weight; nd- not detected. In each row, different letters mean significant differences between samples $(p<0.05)$. The number of replications was $n=9$. 